\title{
Results of Monitoring the Development of Children's Tolerance in a Family Club
}

\author{
Liudmila G. Klimatckaia a*, Natalia Iu. Romanova ${ }^{a, b}$ \\ and Elena D. Bektiashkina ${ }^{\mathrm{a}}$ \\ ${ }^{a}$ Krasnoyarsk State Pedagogical University \\ named after V.P. Astafiev \\ 89 Lebedeva Str., Krasnoyarsk, 660049, Russia \\ ${ }^{b}$ Krasnoyarsk State Medical University \\ named after prof. V.F. Voyno-Yasenetsky \\ 1 Partizan Zheleznyak Str., Krasnoyarsk, 660022, Russia
}

Received 19.03.2016, received in revised form 17.05.2016, accepted 29.06.2016

\begin{abstract}
Objective: develop tolerance of healthy children to children with disabilities within a family club and evaluate the monitoring results. The authors assume that the results of the research carried out in 2012-2014 on a limited territory (Severo-Yeniseysky District of the Krasnoyarsk Territory (Krai)) demonstrate the general peculiarities of an environment of the children's development influencing the formation of public opinion and inadequate social attitude of teachers, over-five pre-schoolers, their parents, and, probably, the local residents to children with disabilities.

Research participants: children attending the senior group of the children's preschool education centre and children with disabilities, attending a family club together with their parents.

Methods: monitoring of children's tolerance development in a family club is based on the method by Uruntaeva G.A., Afon'kina Iu.A., modified by Bocharova Iu.Iu., Bektiashkina E.D. for tracing certain moral mindset and empathy with the calculation of toleration levels; significance of difference for dependent samples is calculated with Student's t-test.

Monitoring results: tolerance level has significantly increased ( $p<0.05$, Student's t-test for linked samples, $t_{e x}=2.72$ and 2.55 correspondingly under $\left.t_{c r}=2.20\right)$ in different situations and in summary $(p<0.01$, tex $=6.37, t c r=3.11)$; the most distinctive result: by the end of the research there were no children with inacceptable level of tolerance left. The family club for healthy children, children with disabilities and their parents is successful in tolerance development and improvement of a multistage system of inclusive education. In the scope of a single social organization this objective would hardly be realistic, as a family club on its own may hardly create a social environment tolerant to children with disabilities. However, on a small territory this task was fulfilled, provided that all resources of the district were involved.
\end{abstract}

Keywords: tolerance development, healthy preschool children aged over five, children with disabilities, family club, inclusive education.

DOI: 10.17516/1997-1370-2016-9-8-1702-1709.

Research area: culture studies.

(C) Siberian Federal University. All rights reserved

* Corresponding author E-mail address: klimatskaya47@mail.ru 
Creation of optimal conditions for the successful social development and social adaptation of children, regardless of their health and abilities, is provided by the law on education in the Russian Federation. Nevertheless, a part of children with disabilities still experience some difficulties during their integration into the society (Amonashvili, Sh., 2015; Masharova, T.V., et al., 2014; Dorokhova, T.S., Kudryavtseva, E.O., 2013; Ahsan, M. T., et al., 2014; Morris, J., 2014; Gasser, L., et al., 2014; et al). In Russia it is caused by several reasons, the main of which is the unpreparedness for tolerance towards children with disabilities of the environment and the society members including teachers and parents (Alekhina, S.V., 2012; 54 Kulagina, E.V., 2009; Stepanova, O.A., Iusupov, R.G., 2013; Kelly, A., Barnes-Holmes, D., 2013; Chiner, E., Cardona, M. C., 2013; et al.).

The objective of the research is to develop tolerant attitude of healthy children to children with disabilities within a family club and evaluate the monitoring results.

Hypothesis. For the successful development of tolerance towards children with disabilities, the society needs to meet the following conditions: begin working on changing the attitude towards children with disabilities through organized groups of children attending-pre-school education facilities (PEF); organize some clubs at PEFs for the joint creative activity of teachers, children and their parents, following the legislation and using Russian and foreign experience of integrating children with disabilities into the society; build a pattern of social partnership to facilitate the integration of children with disabilities into the society.

\section{Materials and methods}

The present research was carried out from 2012 till 2014 on the basis of a PEF in SeveroYeniseysky district and a weekend family club created there to organize joint creative activity and facilitate integration of children with disabilities into the society. Events at the club involved the resources available in the district and help of the children's parents. The participants of the research are children of the senior group of the PEF and a heterogenic group of children with disabilities attending the family club with their parents. The level of tolerance of healthy children to children with disabilities was evaluated with the diagnostic method of "Story pictures" by Uruntaeva G.N. and Afon'kina Iu.V. modified by Bocharova Iu.Iu., Bektiashkina E.D. and given a score. The maximum score on each scale is 6 , the maximum total score is 24 . The more score a respondent gets, the higher is his/ her level of tolerance; the score ranging from 24 to 17 is favourable level, from 16 to 9 is relatively acceptable level, and from 8 to 0 is unacceptable level.

Used statistic methods: determination of difference significance for linked samples with Student's t-test.

\section{Research results}

A procedure for monitoring integration and socialization processes of preschool over-fives and children with disabilities was developed. The monitoring procedure included observation of the children's creative activities in games, study of photographs and video records of interaction between the children; criteria for such moral representations as care - indifference, generosity - greediness, industriousness laziness, truthfulness - untruthfulness and the system for evaluation in score were developed. Table 1 presents the results of the tolerance level monitoring of the healthy children.

As we see in Table 1, the tolerance level in the situations of care - indifference, generosity greediness significantly increased $(p<0.05$; Student's criterion for linked samples, $t_{\mathrm{ex}}=2.72$ 
Table 1. Results of the tolerance level monitoring of the healthy children (started in 2012, finished in 2014)

\begin{tabular}{|c|c|c|c|c|c|}
\hline \multirow{2}{*}{ Respondent No. } & \multicolumn{5}{|c|}{ Tolerance levels in different situations, score } \\
\cline { 2 - 6 } & $\begin{array}{c}1 \\
\text { Care - } \\
\text { indifference }\end{array}$ & $\begin{array}{c}2 \\
\text { Generosity - } \\
\text { greediness }\end{array}$ & $\begin{array}{c}3 \\
\text { Industriousness - } \\
\text { laziness }\end{array}$ & $\begin{array}{c}\text { Truthfulness - } \\
\text { untruthfulness }\end{array}$ & Total score \\
\hline No. 1 & $4 / 5$ & $6 / 6$ & $4 / 5$ & $3 / 5$ & $17 / 21$ \\
\hline No. 2 & $4 / 6$ & $4 / 5$ & $6 / 5$ & $3 / 6$ & $17 / 22$ \\
\hline No. 3 & $4 / 4$ & $3 / 5$ & $4 / 5$ & $4 / 6$ & $15 / 20$ \\
\hline No. 4 & $3 / 6$ & $6 / 6$ & $4 / 6$ & $6 / 6$ & $19 / 24$ \\
\hline No. 5 & $6 / 6$ & $3 / 4$ & $3 / 3$ & $3 / 4$ & $15 / 17$ \\
\hline No. 6 & $1 / 5$ & $4 / 4$ & $3 / 3$ & $3 / 3$ & $11 / 15$ \\
\hline No. 7 & $3 / 5$ & $3 / 3$ & $2 / 4$ & $2 / 4$ & $10 / 14$ \\
\hline No. 8 & $4 / 4$ & $4 / 4$ & $2 / 2$ & $6 / 6$ & $16 / 16$ \\
\hline No. 9 & $2 / 2$ & $2 / 2$ & $2 / 2$ & $2 / 3$ & $8 / 10$ \\
\hline No. 10 & $3 / 3$ & $2 / 2$ & $3 / 4$ & $2 / 2$ & $10 / 11$ \\
\hline No. 11 & $3 / 4$ & $0 / 2$ & $3 / 1$ & $2 / 3$ & $8 / 10$ \\
\hline No. 12 & $6 / 6$ & $4 / 5$ & $4 / 5$ & $5 / 6$ & $19 / 22$ \\
\hline
\end{tabular}

and 2.55 correspondingly with $\left.\mathrm{t}_{\mathrm{cr}}=2.20\right)$, in the situations of truthfulness - untruthfulness the tolerance level significantly increased $\left(\mathrm{p}<0.01, \mathrm{t}_{\mathrm{ex}}=3.76, \mathrm{t}_{\mathrm{cr}}=3.11\right)$. The indicators for industriousness - laziness did not show any significant dynamics, which may be explained with its low communicative dependence. The total level of tolerance significantly increased $(\mathrm{p}<0.01$, $\left.\mathrm{t}_{\mathrm{ex}}=6.37, \mathrm{t}_{\mathrm{cr}}=3.11\right)$. Positive change of tolerance shown by the pre-schoolers is demonstrated in Figure 1.

Monitoring results of the tolerance level of the healthy children expressed with a three-score scale are presented in Table 2.

Comparing the shares of children with the favourable tolerance level in the monitoring process, we may state that the situation has significantly changed: the proportion has grown from 33 to 58 per cent. Undoubtedly, a principally positive result is the absence of children with an unacceptable tolerance level in the club at the end of the research.

Similar results demonstrating the influence of the joint creative activity on the growth of tolerance in monitoring research were obtained by some other authors (Maller, A.R., 2015; Sirotiuk, A.S., 2014; Shipitsyna, L.M., 2015).

Club activities efficiently shape up and develop interpersonal relations due to lively communication between both healthy children and children with disabilities (Fetisova, A.V., 2014). The activity of family clubs in the Krasnoyarsk Territory (Krai) shows that efficient interaction in the system of "a family with a healthy child teachers - a family with a child with disabilities" facilitates development of tolerant attitude of all participants of such interaction and fits our experiment.

The research promotes the idea that development of a tolerant attitude of healthy children to children with disabilities leads to the development of tolerance in the local society. It becomes possible because parents attending the club at the PEF also work on their level of tolerance together with their children (Bektiashkina, E.D. et al., 2015). Due to the limitedness of the territory, these people and their immediate environment tightly interact with different structures of the districts, or represent the administration, social security 

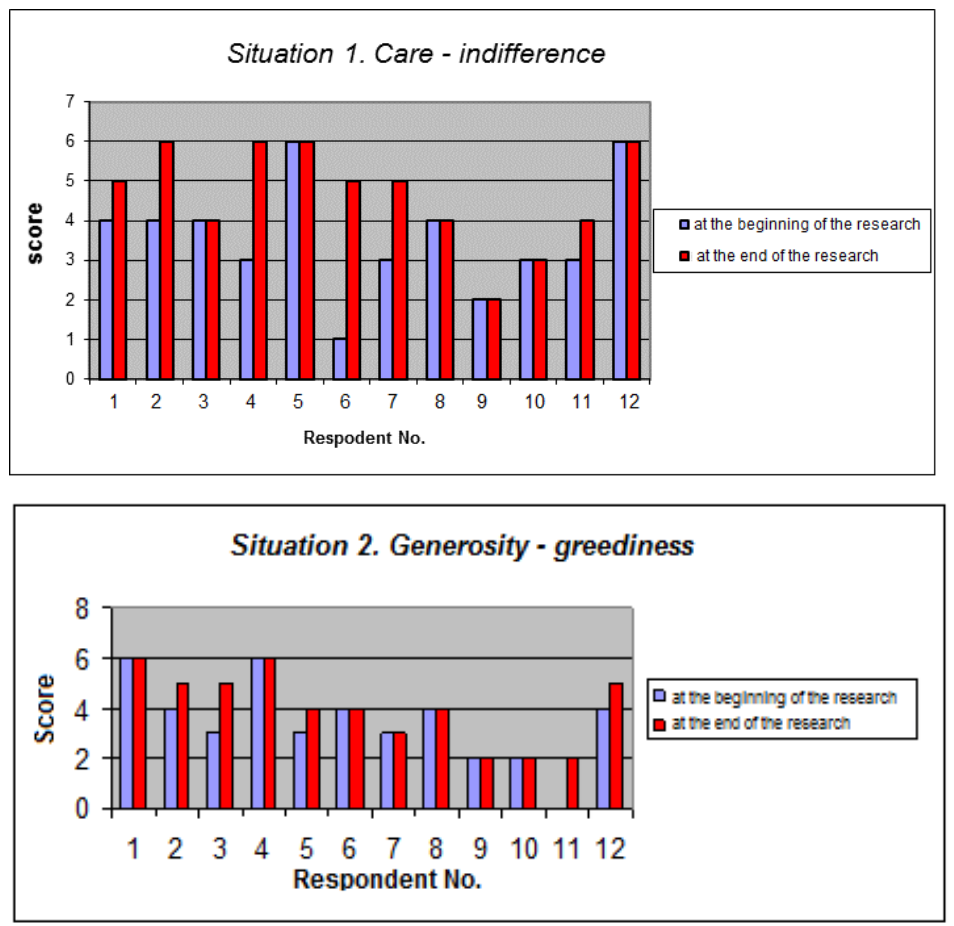

Situation 3. Industriousness - laziness

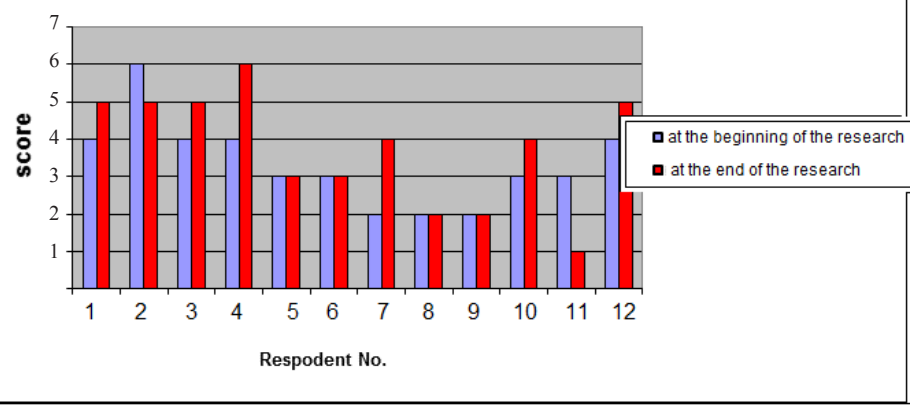

Fig. 1. Change of tolerance of preschool-aged children in the situations of care - indifference, generosity greediness, industriousness - laziness, truthfulness - untruthfulness, total development level (score)

bodies, the bodies of public health, culture, social and religious organizations etc. The interaction grew into a consistent sustainable pattern of social partnership in the district.

\section{Conclusions}

1. It is proved that children of pre-school age attending pre-school education facilities and a family club develop tolerant attitude to children with disabilities more successfully than others. The data of the three years' monitoring shows, that the level of tolerance of such children significantly increased $(\mathrm{p}<0.05$, Student's t-test for linked samples, $t_{\mathrm{ex}}=2.72$ and 2.55 correspondingly with $\mathrm{t}_{\mathrm{cr}}=2.20$ ) in different situations and in total $(\mathrm{p}<0.01$, $t_{\text {ex }}=6.37, t_{c r}=3.11$ ), by the end of the research there were no children with unacceptable level of tolerance left.

2. It has been proved that the family club was the key point in the development of tolerance by creating conditions for changing 

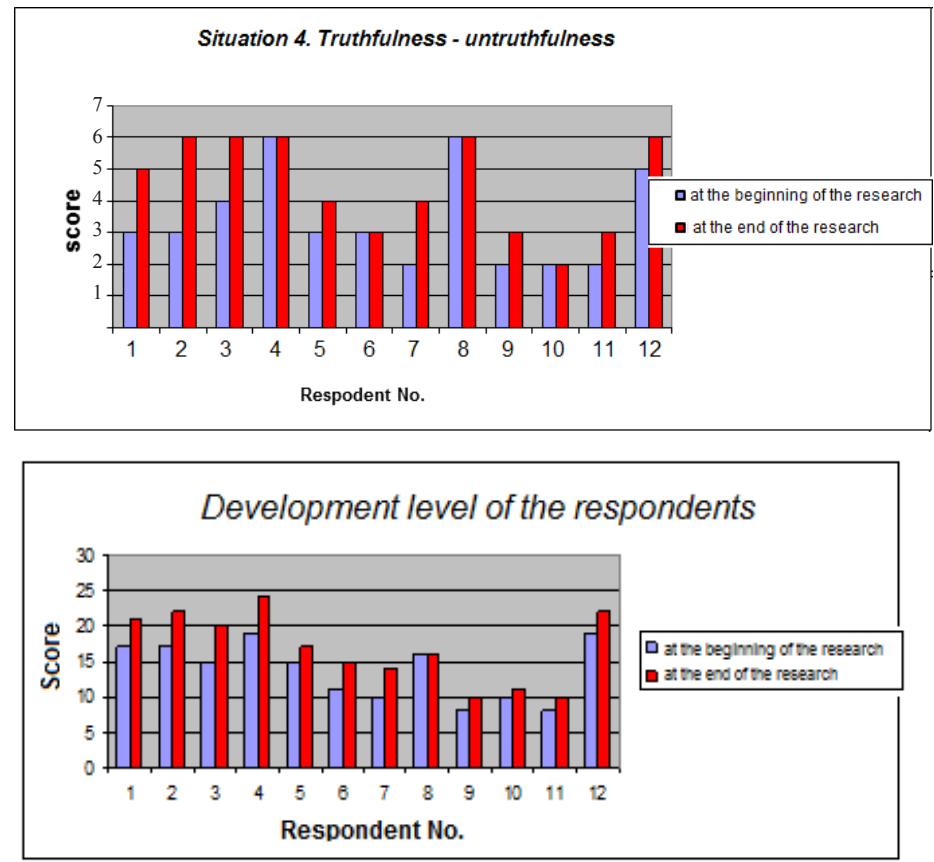

Fig. 1. Continue

Table 2. Monitoring results of the tolerance level of the healthy children expressed with a three-score scale

\begin{tabular}{|l|c|c|}
\hline \multirow{2}{*}{ Tolerance level of the healthy children } & \multicolumn{2}{|c|}{ Number of children, per cent } \\
\cline { 2 - 3 } & At the beginning of the research & At the end of the research \\
\hline Unacceptable & 17 & 0 \\
\hline Relatively acceptable & 50 & 42 \\
\hline Favourable & 33 & 58 \\
\hline
\end{tabular}

the attitude of people living in a small territory towards children with disabilities. The club involved children and their parents into joint creative facilities, expanded the range of social partnership events using the resources available in the district, drawing the attention of the community to the problems of families bringing up children with disabilities.

3. The developed pattern of social partnership for integration of children with disabilities into the community may be recommended for other small territories.

\section{References}

Alekhina, S.V. (2012) Spetsial'naia pedagogika [Special Pedagogics], In Vestnik, 117.

Amonashvili, Sh (2015) Osnovy gumannoy pedagogiki. Kniga 1. Ulybka moia, gde ty? [Basic Humane Pedagogics. Book 1. Where Are You, My Smile?] Litres.

Bektiashkina, E.D., Klimatskaia, L.G., Romanova, N.Iu. (2015) Formirovanie tolerantnogo otnosheniia zdorovykh detey starshego doshkol'nogo vozrasta $k$ detiam s ogranichennymi vozmozhnostiami zdorov'ia $v$ usloviiakh semeynogo kluba [Development of Tolerant Attitude of 
Healthy Pre-School Over-Fives to Children With Disabilities in a Family Club], In Sibirskiy vestnik spetsial'nogo obrazovaniia [Siberian Newsletter of Special Education], (2), 13-17.

Bobrova, E., Bakhshieva, S., Grishkevich, N., Zaytseva, O., Panicheva, E., Reusheva, S., \& Evert, L. (2014). Emotsional'no-povedencheskie rasstroystva u shkol'nikov iuzhnykh regionov Sibiri s sinkopal'nymi sostoianiiami [Emotional and Behavioural Disorders of School Students with Syncopal Conditions from South Regions of Siberia], In Mezhdunarodnyy zhurnal prikladnykh ifundamental'nykh issledovaniy [International Journal of Applied and Fundamental Research], (9-2).

Dorokhova, T.S., \& Kudriavtseva, E.O. (2013) Sotsial'no-pedagogicheskaia deiatel'nost's det'mi s ogranichennymi vozmozhnostiami zdorov'ia $v$ doshkol'nom obrazovatel'nom uchrezhdenii [Social and Pedagogic Activities with Children with Disabilities at a Pre-School Educational Facility], In Vestnik sotsial'no-gumanitarnogo obrazovaniia i nauki [Social-Humanitarian Education and Science Newsletter], (2), 37-41.

Zaytseva, O.I., Derevtsova, S.N., Evert, L.S., Pulikov, A.S., \& Moskalenko, O.L. (2012) Variatsii psikhovegetativnogo statusa i adaptatsionnye vozmozhnosti shkol'nikov, prozhivaiuschikh $v$ razlichnykh regionakh Sibiri [Variations of Psychovegetative Status and Adaptation Abilities of School Students Resident in Various Regions of Siberia], In Vestniknovykh meditsinskikh tekhnologiy [New Medical Technologies Newsletter], 19(2).

Kulagina, E.V. (2009) Obrazovanie detey s ogranichennymi vozmozhnostiami zdorov'ia. Opyt korrektsionnykh i integratsionnykh shkol [Education of Children with Disabilities. Experience of Remedial and Integration Schools], In Sotsiologicheskie issledovaniia [Sociological Research], (2), 107-116.

Maller, A.R. (2015) Problema integratsii detey s vyrazhennymi narusheniiami razvitiia [Problem of Integration of Children with Distinctive Development Disorders], In Spetsial'noe obrazovanie [Special Education], 1(XI).

Masharova, T.V., Saltykova, M.A., \& Krestinina, I.A. (2014) Regional'naia model' kompleksnogo soprovozhdeniia inkliuzivnykh form obucheniia i vospitaniia detey-invalidov i detey s ogranichennymi vozmozhnostiami zdorov'ia [Regional Model of Comprehensive Support of Inclusive Education and Upbringing of Handicapped Children and Children with Disabilities], In BBK 74.3 (2 Ros-4 Ki) M 74, $27,96$.

Sitarov, V.A. (2012). Nenasil'stvennye tekhnologii organizatsii obucheniia $i$ vospitaniia detey $v$ obrazovatel'nykh uchrezhdeniiakh [Non-Violent Technologies of Education and Upbringing of Children at Educational Facilities], In Znanie. Ponimanie. Umenie [Knowledge. Understanding. Skill], (3).

Sirotiuk, A.S. (2014) Formirovanie tolerantnosti u detey doshkol'nogo vozrasta v usloviiakh inskliuzivnoy razvivaiuschey sredy [Developing Tolerance of Over-Fives Within an Inclusive Developmental Environment]. Directmedia.

Skripkina, T.P., \& Karabanova, O.A. (2011) Sotsiokul'turnyetekhnologiiformirovaniia sotsial'nogo $i$ individual'nogo tolerantnogo povedeniia [Sociocultural Technologies of Developing Social and Individual Tolerant Behaviour], In Natsional'nyy psikhologicheskiy zhurnal [National Psychological Journal], (2).

Stepanov, O. (2001) Kak vospitat' tolerantnost'? [How to Teach Tolerance?], In Narodnoe obrazovanie [People's Education], (9), 91-97. 
Stepanova, O.A., \& Iusupov, R. (2013) Gosudarstvennaia programma Rossiyskoy Federatsii "Razvitie obrazovaniia" na 2013-2020 gody: inkliuzivnyy kontekst [National Programme of the Russian Federation for the Development of Education for the Years 2013-2020: Inclusive Context], In Vestnik UGUES. Nauka, obrazovanie, ekonomika. Seriia: Ekonomika [Ufa State University of Economics and Service Newsletter. Science, Education, Economics. Economics Series], (1-(3)).

Tolmacheva, G.A. (2013) Normativno-pravovye osnovy obrazovaniia detey s ogranichennymi vozmozhnostiami zdorov'ia [Regulatory Legal Basics of Educating Children with Disabilities], In Psikhologo-pedagogicheskiy poisk [Psychological Pedagogical Search], (3), 27.

Uruntaeva, G.A., Afon'kina, Iu.A. (1995) Praktikum po detskoy psikhologii [Children's Psychology Practicum].

Fadeev, S.B. (2012) Suschnost' tolerantnosti kak mnogoaspektnogo fenomena [Meaning of Tolerance as a Multiaspect Phenomenon], In Vestnik Cheliabinskogo gosudarstvennogo pedagogicheskogo universiteta [Chelyabinsk State Pedagogical University Newsletter], (3).

Fetisova, A.V. (2014) Molodezh s ogranichenymi vozmozhnostiami kak ob’ekt molodezhnoy politiki [Youth With Disabilities as an Object of Youth Policy]. Science Time, (5 (5)).

Shipitsyna, L.M. (2015) Spetsial'naia psikhologiia v reshenii zadach inkliuzivnogo obrazovaniia detey s ogranichennymi vozmozhnostiami zdorov'ia [Special Psychology in Solving the Tasks of Inclusive Education of Children with Disabilities]. Redaktsionnaia kollegiia, 256.

Iarskaia-Smirnova, E.R. (2015) Muzhestvo invalidnosti [The Courage of Disability], In Zhurnal issledovaniy sotsial'noy politiki [Social Politics Research Journal].

Ahsan, M. T., Sharma, U., \& Deppeler, J. M. (2012). Exploring Pre-Service Teachers' Perceived Teaching-Efficacy, Attitudes and Concerns about Inclusive Education in Bangladesh. International Journal of whole schooling, 8(2), 1-20.

Ali, A., Hassiotis, A., Strydom, A., \& King, M. (2012). Self stigma in people with intellectual disabilities and courtesy stigma in family carers: A systematic review. Research in developmental disabilities, 33(6), 2122-2140.

Chiner, E., \& Cardona, M. C. (2013). Inclusive education in Spain: how do skills, resources, and supports affect regular education teachers' perceptions of inclusion? International Journal of Inclusive Education, 17(5), 526-541.

Gasser, L., Malti, T., \& Buholzer, A. (2014). Swiss children's moral and psychological judgments about inclusion and exclusion of children with disabilities. In Child development, 85(2), 532-548.

Kelly, A., \& Barnes-Holmes, D. (2013). Implicit attitudes towards children with autism versus normally developing children as predictors of professional burnout and psychopathology. In Research in developmental disabilities, 34(1), 17-28.

Illingworth, R. S. (2013). The development of the infant and the young child: Normal and abnormal. Elsevier Health Sciences.

Morris, J. (2014). Pride against prejudice: Transforming attitudes to disability.

Saravanan, C., \& Rangaswamy, K. (2012). Effectiveness of counselling on the attitudes of mothers towards their children with intellectual disability. In Asia Pacific Journal of Counselling and Psychotherapy, 3(1), 82-94. 
Starczewska, A., Hodkinson, A., \& Adams, G. (2012). Conceptions of inclusion and inclusive education: a critical examination of the perspectives and practices of teachers in Poland. In Journal of Research in Special Educational Needs, 12(3), 162-169.

\title{
Итоги мониторинга
}

\section{формирования толерантности}

\section{у детей в условиях семейного клуба}

\author{
Л.Г. Климацкая ${ }^{a}$ Н.Ю. Романова ${ }^{\sigma}$, Е.Д. Бектяшкина ${ }^{a}$ \\ ${ }^{a}$ КГПУ им. В.П. Астафьева \\ Россия, 660049, Красноярск, ул. Ады Лебедевой, 89 \\ ${ }^{\sigma}$ КрасГМУ им В.Ф. Войно-Ясенеикого \\ Россия, 660022, Красноярск, ул. Партизана Железняка, 1
}

Цель: сформировать толерантное отномение здоровых детей к детям с ограниченными возможностями здоровья (ОВЗ) в условиях семейного клуба и оценить итоги мониторинга. Предполагалось, что результаты исследования, проведенного в 2012-2014 годах в малой территории (Северо-Енисейский район Красноярского края), отражают особенности организации развивающей среды, способствующей изменению общественного мнения и неадекватных социальных проявлений у педагогов, детей старшего дошкольного возраста и их родителей и, возможно, жителей района к детям с ОВЗ.

Участники исследования: дети старшей группы детского образовательного учреждения и дети с ОВЗ, вместе посещающие семейный клуб со своими родителями.

Методы: мониторинг формирования толерантности у детей в условиях семейного клуба на основе методики Г.А. Урунтаевой, Ю.А. Афонькиной, в модификации Ю.Ю. Бочаровой, Е.Д. Бектямкиной для отслеживания определенных нравственных установок и эмпатии с расчетом уровней толерантности; достоверность различий для зависимых выборок по t-критерию Стьюдента.

Итоги мониторинга: уровень толерантности значимо возрос $(p<0,05, t$-критерий Стьюдента для связных выборок, топ $=2,72$ и 2,55 соответственно при ткр= 2,20) по различным ситуачиям и суммарно ( $<<0,01$, ton=6,37, tкр=3,11); наиболее выраженный результат: на конеи исследования среди детей не осталось испытуемых с недопустимым уровнем толерантного поведения. Семейный клуб для здоровых детей, детей с ОВЗ и их родителей успешно формирует толерантность и способствует совершенствованию многоступенчатой системы инклюзивного образования. В масштабе отдельно взятой общественной организации данная задача была бы невыполнима, поскольку самостоятельно семейный клуб едва ли в силах сформировать сочиальную среду, толерантную к детям с ОВ3. Однако в малой территории при привлечении всех ресурсов района эта задача была решена.

Ключевые слова: формирование толерантности, здоровые дети старшего дошкольного возраста, дети с ограниченными возможностями здоровья, семейный клуб, инклюзивное образование.

Научная специальность: 24.00.00 - культурология. 